\section{Polyploidy as a Management Strategy for Invasive Species}

\author{
Kenneth W. Leonhardt ${ }^{1}$
}

\begin{abstract}
Additional index words. Cassia, Delonix, induced sterility, Spathodea, Albizia
SuMmary. Most invasive species are prolific seed-producing landscape ornamental plants that have been introduced to non-native habitats with limited or no natural controls on their reproduction and spread. Techniques for converting prolific seedproducing landscape ornamentals into sterile or nearly sterile forms are available. Oryzalin and colchicine have been used to double chromosomes, resulting in autotetraploids with reduced fertility and potential parent plants of sterile triploids. Guard cell measurements and flow cytometry have been used to determine ploidy conversion and identify polyploids. Complete sterility has been achieved in three species of shower trees (Cassia sp.), and up to a $95 \%$ reduction in seed production has been achieved in royal poinciana (Delonix regia) and african tulip tree (Spathodea campanulata). Monkey pod (Albizia saman) crosses have produced triploid progeny to evaluate for sterility.
\end{abstract}

W ith human movement comes the arrival of invasive species. Since humans started migrating to new places, new plants intentionally came with them for agricultural or ornamental purposes. New plants also came unintentionally, via seeds that hitchhiked on clothing, animals, and ships. The advent of widespread human movement ushered collateral damage from a previously unconsidered source: invasive species. The U.S. Department of Agriculture identifies invasive species by two key criteria: 1 ) that it is a non-native species and 2) that its introduction "causes or is likely to cause economic or environmental harm or

Received for publication 25 Feb. 2019. Accepted for publication 11 July 2019.

Published online 27 August 2019.

${ }^{1}$ Department of Tropical Plant and Soil Sciences, University of Hawaii, 3190 Maile Way, St. John 102, Honolulu, HI 96822-2279

This work was supported by the U.S. Department of Agriculture National Institute of Food and Agriculture, Hatch project 819 , managed by the College of Tropical Agriculture and Human Resources, University of Hawaii.

The assistance of Dr. Karen Selph, Specialist and Graduate Faculty, Department of Oceanography, and Director of the School of Ocean and Earth Science and Technology Flow Cytometry Facility, University of Hawaii at Manoa, is greatly appreciated.

This paper was part of the Invasive Plants Research Professional Interest Group workshops "Strategies for Mitigating Invasiveness of Native Species," held 30 Sept. 2017 in Waikoloa, HI, and "It's Native. Wait! It's Exotic .... Oh No, It's a Nuisance!" held 3 Aug. 2018 in Washington, DC.

K.W.L. is the corresponding author. E-mail: leonhard@hawaii.edu.

This is an open access article distributed under the $\mathrm{CC}$ BY-NC-ND license (https://creativecommons.org/ licenses/by-nc-nd/4.0/).

https://doi.org/10.21273/HORTTECH04324-19 harm to human health" (U.S. Department of Agriculture, n.d.).

Invasive species can spread easily and cause significant ecological damage (Blackburn et al., 2011; Pyšek and Richardson, 2010; Vilà et al., 2011). They are also responsible for great economic loss-an estimated \$120 billion in 2004 (Pimentel et al., 2005). Few comprehensive studies related to the economic impact of invasive species have been published since that of Pimentel et al. (2005), but it is recognized that invasive species continue to have an impact on local ecosystems' endangered species. Invasive plant species are detrimental to $42 \%$ of endangered species in the United States and 18\% of endangered species in the United States have invasive plant species as the primary cause of their decline (U.S. Department of Agriculture, n.d.).

Invasive species are clearly a problem and one of the key parameters used to classify them as invasive is their seed production. High seed production compared with native species is one of the parameters that makes an introduced species invasive (James et al., 2010). The success of many invasive trees is attributed to their seed fecundity (Pheloung et al., 1999; Wickert et al., 2017). Some of the most invasive trees, such as miconia (Miconia calvescens) are invasive primarily because of their prolific seed production. A single $10-\mathrm{m}$ tree with 100 inflorescences, 300 fruit/ inflorescence, and 100 seeds/fruit, will produce 3 million seeds two to three times per year (Medeiros and Loope, 1997).

The distribution of ornamentals in horticulture is a familiar mechanism of an invasive species' introduction (Dehnen-Schmutz et al., 2007; Pemberton and Liu, 2009; Reichard and White, 2001). Inducing sterility could prevent otherwise invasive species from taking hold in non-native ecosystems. Creating tetraploid forms of potentially invasive ornamentals offers two opportunities to induce sterility by altering the mechanism for seed production. Because reproduction is an essential component of the stages in which an introduced species becomes invasive (Blackburn et al., 2011), inhibiting seed production is an effective strategy to arrest the invasiveness of an introduced species. Tetraploid forms of ornamentals are sometimes sterile (Leonhardt, $2016,2017 \mathrm{~b}$ ) or have highly reduced seed production capability (Leonhardt and Shi, 2009). If the tetraploid form is fertile, it can be crossed with a diploid form of the same species (Vining et al., 2012). A successful cross between tetraploid and diploid plants results in triploid progeny. Most triploids are highly sterile (Ranney, 2000; Vining et al., 2012).

Polyploidy does not ensure sterility. There are many examples of highly fertile polyploidy species that have become invasive. For example, the tetraploid form of purple loosestrife, Lythrum salicaria, is invasive in 13 states of the United States and provinces of Canada (Kubatova et al., 2008 ) and the tetraploid form of reed

\begin{tabular}{llll}
\hline $\begin{array}{l}\text { Units } \\
\text { To convert U.S. to SI, } \\
\text { multiply by }\end{array}$ & U.S. unit & SI unit & $\begin{array}{l}\text { To convert SI to U.S., } \\
\text { multiply by }\end{array}$ \\
\hline 29,574 & $\mathrm{fl} \mathrm{oz}$ & $\mu \mathrm{L}$ & $3.3814 \times 10^{-5}$ \\
0.3048 & $\mathrm{ft}$ & $\mathrm{m}$ & 3.2808 \\
0.0929 & $\mathrm{ft}^{2}$ & $\mathrm{~m}^{2}$ & 10.7639 \\
2.54 & inch(es) & $\mathrm{cm}$ & 0.3937 \\
25.4 & inch(es) & $\mathrm{mm}$ & 0.0394 \\
6.4516 & inch $^{2}$ & $\mathrm{~cm}^{2}$ & 0.1550 \\
1 & micron(s) & $\mu \mathrm{m}$ & 1
\end{tabular}


canarygrass (Phalaris arundinacea) is an invasive grass species on the Turnbull National Wildlife Refuge in the state of Washington (Canwell 2015).

The studies reported here deal with reducing or eliminating seed production as a means of invasiveness, which is not meant to imply that clonal propagation cannot also lead to invasiveness. Kahili ginger (Hedychium gardnerianum), yellow ginger $(H$. flavescens), and white ginger (H. coronar$\mathrm{ium}$ ) are seed-producing, herbaceous, perennial monocots but have massive spreading mats of short stout rhizomes that crowd out seedlings of native and exotic species in wet forest, roadsides, open areas, and streamsides (New Zealand Plant Conservation Network, n.d.). This appears to be the primary means of their invasiveness in Hawaii. Water lily (Nymphaea sp.) and hybrids may produce seed, but their colonization of ponds, ditches, canals, and slowmoving streams in Hawaii is mostly caused by their rapid spreading rhizomes and sometimes stolons, and in some tropical day-blooming varieties, the viviparous production of clonal plantlets at the connection of petiole and leaf pad (personal observations).

The common coral tree (Erythrina $\times$ sykesii) is an invasive species in parts of Australia, although it is a nonseedproducing sterile hybrid (putatively E. coralloides $\times$ E. lysistemon). Logs, branches, twigs, and other vegetative parts spread during flash floods and propagate into new plants. Distribution has also been aided by the dumping of garden waste (Queensland Government, 2016).

The objective was to produce tetraploid forms of three species of shower trees [pink shower tree (Cassia bakeriana), golden shower tree (C. fistula), and white shower tree (C. javanica)], royal poinciana tree, african tulip tree, monkey pod tree, and indian coral tree (Erythrina variegata), and cross them to diploid forms of the same species to produce sterile triploid plants that would be low maintenance for lack of seed pod litter and would not become invasive. The hypothesis was that the tetraploid state could be achieved with the use of the mitotic inhibitors colchicine and oryzalin.

\section{Materials and methods}

In a series of experiments conducted by the author beginning in 2005, the chemical mutagens colchicine and, later, oryzalin were used to convert several tropical landscape species to tetraploid forms by treating the meristems of seedlings with saturated, small cotton balls (Leonhardt and Shi, 2009). Colchicine is an alkaloid and oryzalin is a dinitroaniline herbicide. Colchicine has proved to be a useful tool in many breeding programs aimed at producing superior cultivars (Kamemoto, 1985; Kamemoto et al., 1997; Tambong et al., 1998; Vainola, 2000), and producing sterile triploids by breeding induced tetraploids with diploids (Blakesley et al., 2002; St. Marseille and Grant 1997). Similarly, oryzalin has been shown to double the chromosome numbers in catnip [Nepeta sp. (Mitrofanova et al., 2003)], alocasia [Alocasia sp. (Thao et al., 2003)], rhododendron [Rhododendron hybrids (Vainola, 2000)], and lily [ Lilium sp. (van Tuyl et al., 1990)]. Research has shown that colchicine and oryzalin have a similar mode of action at the molecular level. Both agents bind to plant microtubules that are involved in chromosome migration. Both agents disrupt mitosis by inhibiting spindle fiber formation at metaphase (Strachan and Hess, 1983), resulting in an increase in the chromosome number of the daughter cells. The new growth from treated meristems is compared with the new growth of untreated controls for morphological differences. If there are discernable differences, those plants are subjected to guard cell screening (Leonhardt and Shi, 2009).

Guard Cell measurements. Measuring stomatal guard cells requires producing an imprint of the abaxial side of the leaf of interest. The imprint is then viewed under the microscope and the size of the guard cells is measured. The theory behind this method of screening for changes in ploidy levels is simple. The cell volume of a plant is directly proportional to the amount of DNA present in the cell, so that doubling the amount of DNA, which occurs when diploids are converted to tetraploids, causes the cell to double its volume. Doubling of the volume allows an increase in the size of the cell in any one dimension by 1.25, and comparisons of guard cells among a batch of chemically treated plants allows for the identification of possible polyploids (Russell, 2004). Typically, the ploidy level of the suspected plants identified using guard cell measurements is then verified by performing root tip chromosome counts, a laborious and time-consuming process. Today, more researchers rely on flow cytometry (FCM) for the screening of treated plant material and ploidy-level confirmation. FCM allows for the quantification of plant nuclear DNA, subsequently providing the user with the ploidy level of the samples screened.

Flow CyTometry. A typical flow cytometer contains several components: a light source, a flow chamber and optical assembly, photodetectors and processors to convert light signals into analog electrical impulses, analog-to-digital convertors (ADCs), and a computer system for the analysis and storage of digitized data. Essentially, the plant nuclei are extracted from young leaf tissue using an extraction buffer and labeled with a fluorescent dye (Dirihan et al., 2013; Oates et al., 2014). The sample is then loaded into the cytometer and illuminated, causing the dye to absorb the illuminating light and fluoresce. The emitted light is then converted to electric current pulses, which are fed to amplifiers, digitized using the ADCs, and stored in the computer in the form of a histogram.

CyStain PI Absolute P DNA Staining Kit for Plant Genome Size (Partec, Munster, Germany) was used for nuclei extraction and DNA staining of nuclear DNA from young leaves used for flow cytometric measurement. About $1 \mathrm{~cm}^{2}$ of young leaf tissue was chopped for 30 to $60 \mathrm{~s}$ in a 500$\mu \mathrm{L}$ ice-cold nuclei extraction buffer with a sharp doubled-edge razor blade in a 55-mm plastic petri dish. The slurry was then filtered through a 50$\mu \mathrm{m}$ filter (Cell Trics, Partec) and the suspension of released nuclei was stained in a solution composed of staining buffer, propidium iodide, and RNAse for a final volume of $2 \mathrm{~mL}$.

The relative fluorescence of total DNA of single nuclei was analyzed using a flow cytometer (Altra; Beckman-Coulter, Miami, FL), using the 488-nm line of an argon ion laser (I90C; Coherent, Santa Clara, CA) set at $200 \mathrm{~mW}$. Control diploid plants were used as external standards, and these standards were run intercalated between samples. The linear, log, and peak fluorescence signals, along with forward-and side-scatter signals of the 
propidium iodide-stained nuclei were collected using a 610-bandpass filter, allowing $610 \mathrm{~nm}$ light from propidium iodide-bound DNA to enter the fluorescence detector.

Shower Tree species. At the University of Hawaii Experiment Station at Waimanalo (UHW), Oahu, four golden shower trees (Fig. 1), four pink shower trees, and six pink and white shower trees are all completely sterile as autotetraploids. They have been flowering profusely for several years, but none of them have produced any fruit. Diploid control plants of each species in the same plot are prolific producers of seed pods. Shower tree pod litter must be raked up from lawns before mowing. The littered pods are a nuisance because they are unsightly and often contain a foul-smelling resin (the pink shower tree is particularly malodorous). Like any plant with high seed production, they also have the potential to become invasive. This problem might be avoided entirely by using the autotetraploid forms. These cultivars have no ability to become invasive, making them potentially desirable landscape ornamentals if they could be readily propagated. Unfortunately, only four of $\approx 200$ air layers on the autotetraploid forms rooted, and more than 50 grafts of tetraploid scions onto diploid rootstocks of the same species have failed. Clearly, more research into clonal propagation of polyploid shower trees is needed.

Royal poinciana tree. One royal poinciana tree was successfully converted to the tetraploid form in 2006 and has been flowering at the UHW for at least 6 years. It covers an area of $\approx 800 \mathrm{ft}^{2}$. Diploid trees of similar size produce about 900 to 1000 seed pods/year. The 3-year average pod production for the tetraploid tree is 60 pods, with $\approx 70 \%$ seed abortion. No attempts have been made yet to clone this tree.

African tulip tree. One orange form of the african tulip tree was successfully converted to a tetraploid form. This 12-year-old tree has produced fewer than 15 fruit since it began flowering 7 years ago, whereas diploid forms of comparable size and age produce many hundreds of fruit annually. Reduced or complete cessation of seed production was especially important for the african tulip tree because it is listed as a highly invasive species (Staples et al., 2001). Clonal propagation has not yet been attempted.
In another plot at the UHW, 10 tetraploids, 5 diploid controls, and 19 plants thought to be mixoploids with both $2 \mathrm{~N}$ and $4 \mathrm{~N}$ tissues of the recessive yellow form of the african tulip tree were planted in a randomized block design and are now flowering. The diploid species is self-incompatible. Seed will be harvested and sown and seedlings will be run through the FCM protocol. Triploid seedlings will be grown to maturity and assessed for sterility.
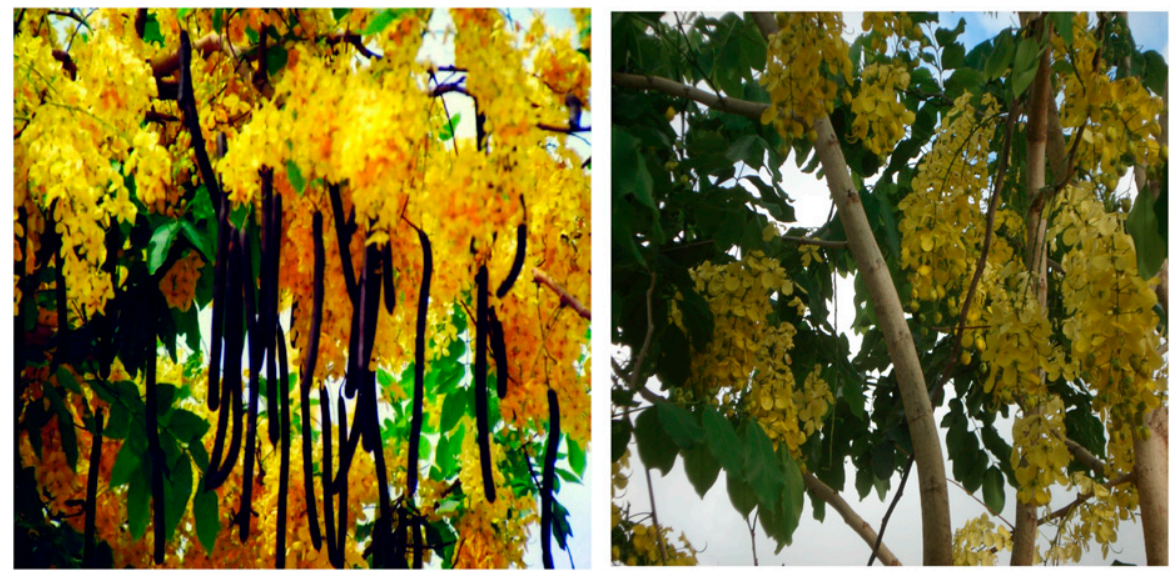

Fig. 1. Golden shower tree. Seed-laden diploid control (left) and completely sterile autotetraploid (right). Unfortunately, the sterile form is not easily propagated.

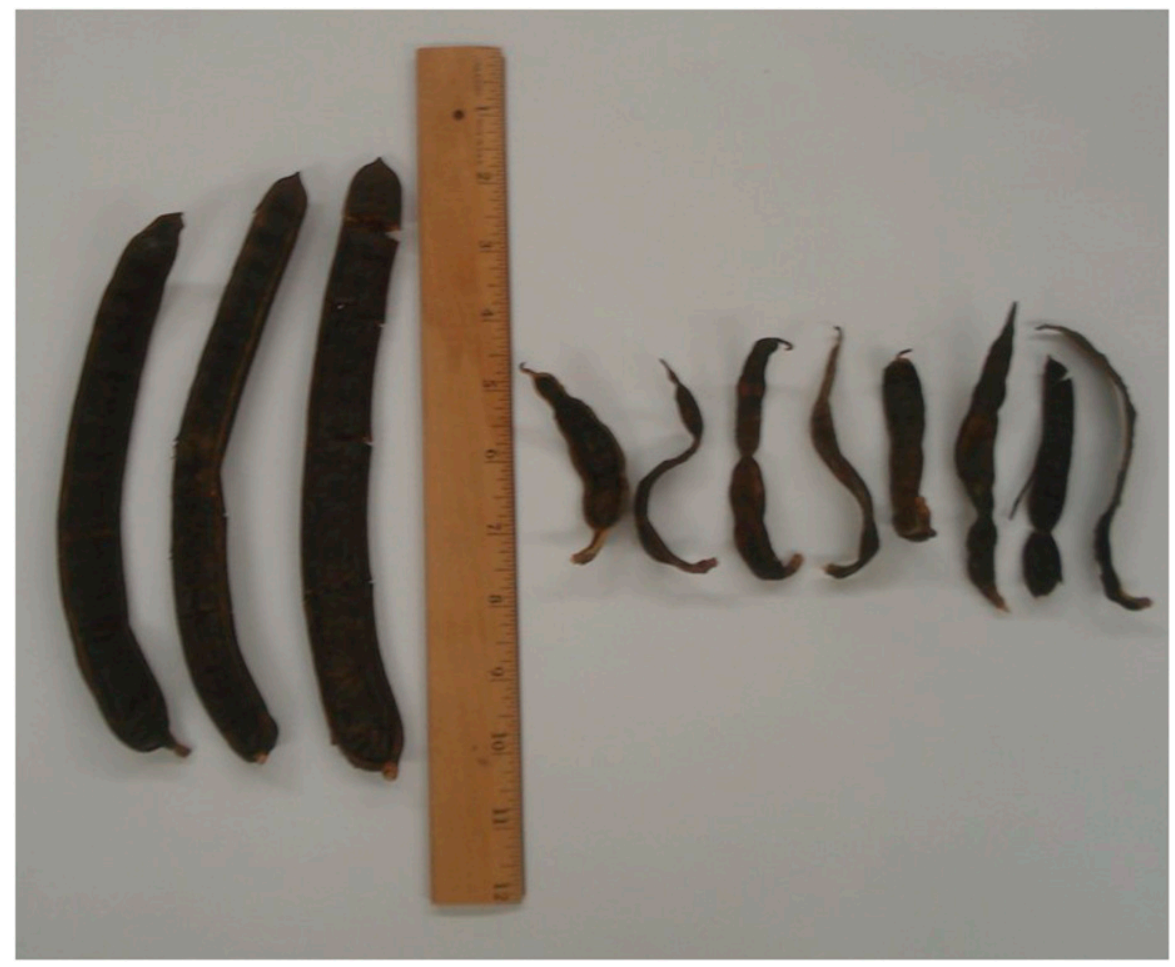

Fig. 2. Monkey pod seed pods from a diploid control tree (left) and from a converted tetraploid tree (right). These pods are seedless. The tree, however, does not consistently produce seedless pods. 
results on 158 seedlings identified 11 triploid plants $(6.96 \%)$ that are now $\approx 2 \mathrm{~m}$ tall and ready for field planting. These plants are expected to be sterile and without seed pods. Attempts to clonally propagate polyploidy monkey pod trees have not yet been done.

\section{Results}

A reduction in seed fecundity of $95 \%$ to $100 \%$ was achieved in several converted species (Leonhardt, 2016, 2017b; Leonhardt and Shi, 2009). These results align with other reports of manipulated ploidy to reduce seed production of invasive species (Oates et al., 2014; Ranney, 2000). The use of polyploidy in breeding programs may be a useful strategy to reduce the harm caused by invasive species.

Polyploidy as an Insect PEST MANAGEMENT STRATEGy. While attempting to create a sterile form of the once popular indian coral tree, it was discovered that polyploid forms of this species are tolerant to an invasive insect pest that has nearly eradicated the diploid species from the Hawaii landscape.

The erythrina gall wasp (EGW; Quadrastichus erythrinae) was first collected in Hawaii in 2005 on the indian coral tree, a then-popular landscape species. It quickly spread to all islands, causing severe damage to the native wiliwili (Erythrina sandwicen$s i s)$ as well as to most introduced species. Galls on leaves, petioles, and stems are induced by the larvae of the tiny EGW. Leaves curl and become massively deformed, and petioles and stems become swollen. Heavy infestations caused defoliation and death of trees (Heu et al., 2008). Many thousands of trees have been killed by this pest. Polyploid individuals of the indian coral tree showed a high level of tolerance to the EGW, whereas in the same field plot, diploid individuals were destroyed. The induction of polyploidy in the EGW-susceptible indian coral tree has produced the EGW-tolerant cultivar Adrien (Fig. 3), which was introduced to the Hawaii landscape industry in 2017 (Leonhardt, 2017a). It is readily propagated by cuttings.

\section{Discussion}

The woody tree species discussed here were amenable to ploidy manipulation and induced sterility. Some of the polyploid plants are now more than
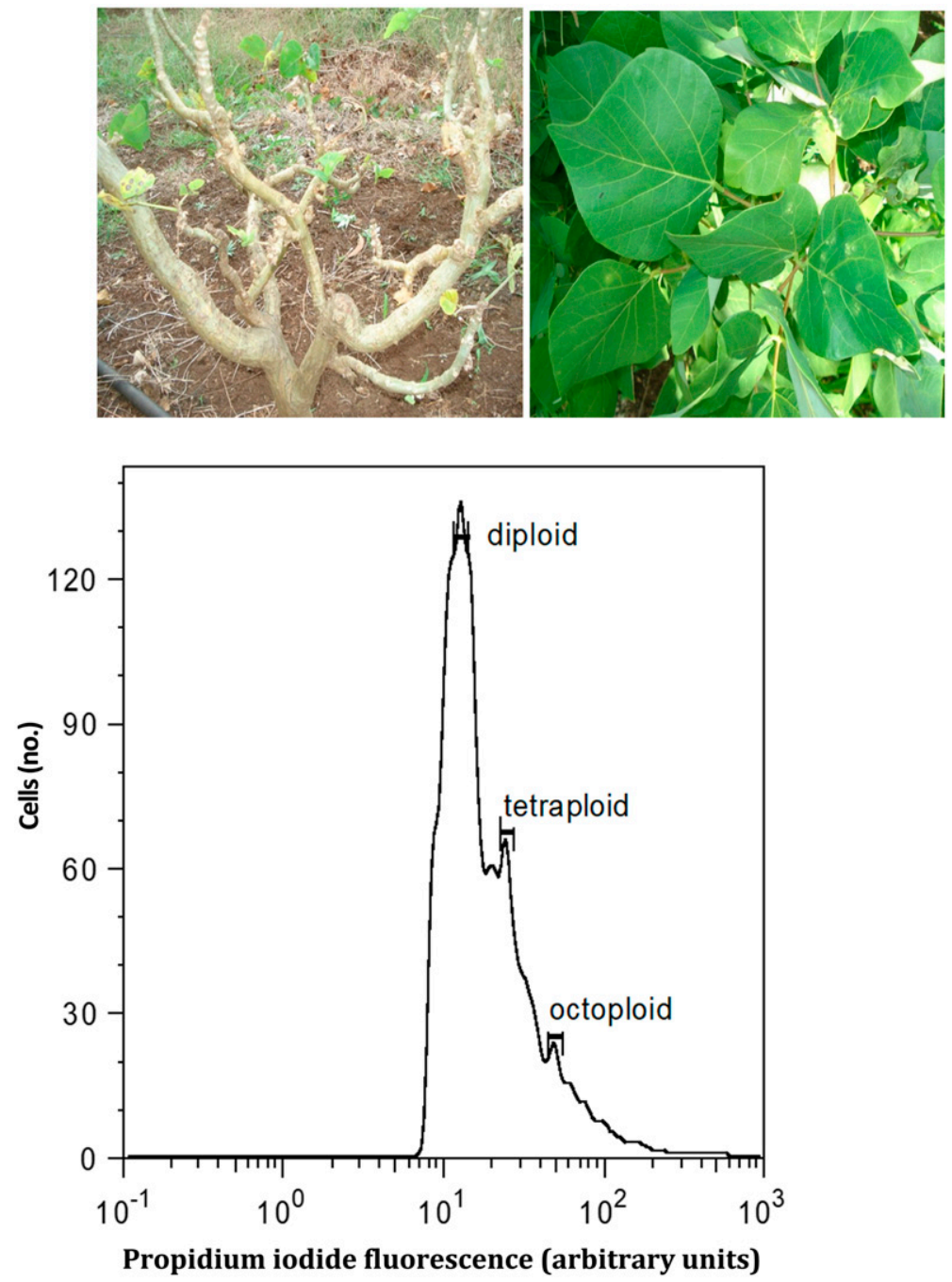

Fig. 3. Erythrina gall wasp (EGW)-susceptible indian coral tree (top left) and EGW-tolerant mixoploid (top right). The mixoploid plant has $23.2 \%$ tetraploid nuclei and $9.6 \%$ octoploid nuclei, as determined by flow cytometry. It was introduced to the landscape trade with the cultivar name Adrien. The histogram (bottom) illustrates the relative quantities of diploid and polyploid nuclei in 'Adrien'.

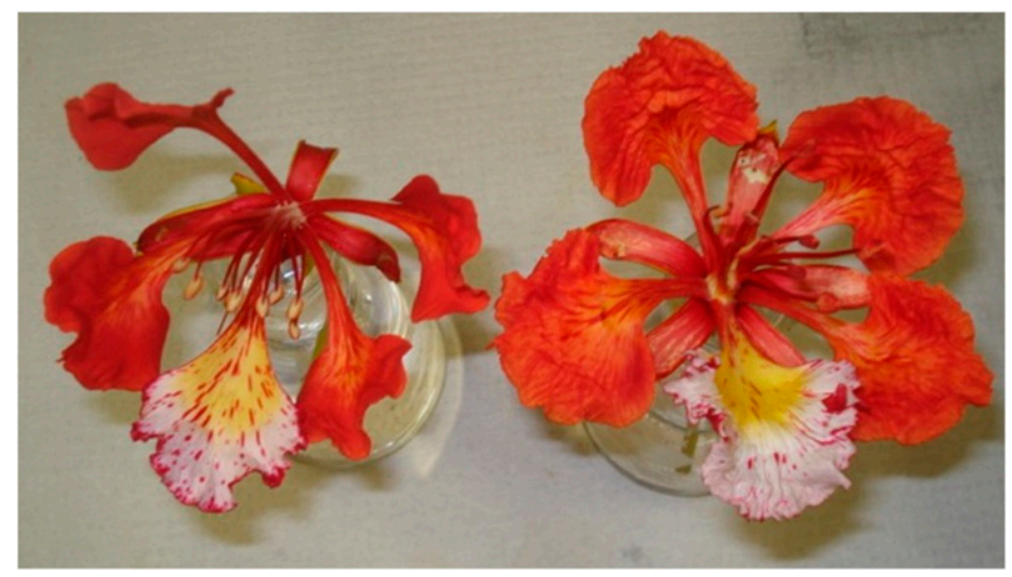

Fig. 4. Flowers from the royal poinciana tree. (Left) Diploid control. (Right) Converted tetraploid. 
12 years old and show few differences from the control plants, other than somewhat larger flowers (Fig. 4) and foliage, and greatly reduced seed production, if not complete sterility. This technology is being applied to additional species of landscape ornamentals that are desirable except for their prolific seed production, such as the highly invasive autograph tree (Clusia rosea) and octopus tree (Schefflera actinophylla), which have been converted to polyploids and field-planted, but have not flowered. This might be an underexploited area of research for invasive species management.

\section{Literature cited}

Blackburn, T.M., P. Pyšek, S. Bacher, J.T. Carlton, R.P. Duncan, V. Jarošík, J.R.U. Wilson, and D.M. Richardson. 2011. A proposed unified framework for biological invasions. Trends Ecol. Evol. 26:333-339.

Blakesley, D., A. Allen, T. Pellny, and A. Roberts. 2002. Natural and induced polyploidy in Acacia dealbata Link. and Acacia mangium Willd. Ann. Bot. 90:391-398.

Canwell, S. 2015. Population genetics of Phalaris arundinacea $\mathrm{L}$. in a western United States wetland. Washington State Univ., Pullman, WA, PhD Diss.

Dehnen-Schmutz, K., J. Touza, C. Perrings, and M. Williamson. 2007. A century of the ornamental plant trade and its impact on invasion success. Divers. Distrib. 13:527-534.

Dirihan, S., P. Terho, M. Helander, and K. Saikkonen. 2013. Efficient analysis of ploidy levels in plant evolutionary ecology. Caryologia Intl. J. Cytol. Cytosystematics Cytogenet. 66:251-256.

Heu, A., D.M. Tsuda, W.T. Nagamine, J.A. Yalemar, and T.H. Suh. 2008. Erythrina gall wasp, Quadrastichus erythrinae Kim (Hymenoptera: Eulophidae): New pest advisory. Hawaii Department of Agriculture, Honolulu, HI.

James, J., B. Smith, E. Vasquez, and R. Sheley. 2010. Principles for ecologically based invasive plant management. Invasive Plant Sci. Mgt. 3:229-239.

Kamemoto, H. 1985. Seed-propagated amphidiploid Dendrobium cultivars. HortScience 20:1-263.

Kamemoto, H., T. Amore, N. Kuanprasert, A. Kuehnle, and N. Sugii. 1997. Evaluation of Dendrobium crosses involving four new amphidiploid parents. Univ. Hawaii Res. Ext. Ser. 166.

Kubatova, B., P. Travnicek, D. Bastlova, V. Curn, V. Jarolimova, and J. Suda. 2008. DNA ploidy-level variation in native and invasive populations of Lythrum salicaria at a large geographical scale. J. Biogeogr. 35:167-176.

Leonhardt, K.W. 2016. Cassia javanica 'Miri' is a new, seedless, pink and white shower tree. Hawaii Landscape Mag. 2016(Nov):16-17.

Leonhardt, K.W. 2017a. 'Adrien', an erythrina gall wasp tolerant coral tree. Hawaii Landscape Mag. 2017(Jan):24-27.

Leonhardt, K.W. 2017b. Cassia fistula 'Pierce', a new and improved, sterile, seedless golden shower tree. Hawaii Landscape Mag. 2017(Mar):8-9.

Leonhardt, K.W. and X. Shi. 2009. Production of tetraploid forms of eight tropical landscape tree species. Acta Hort. 813:133-139.

Medeiros, A.C. and L.L. Loope. 1997. Status, ecology, and management of the invasive plant Miconia calvescens DC (Melastomataceae) in the Hawaiian Islands. Records Hawaii Biol. Survey 1996. Bishop Museum Occasional Papers 48:23-36.

Mitrofanova, I.V., I.R. Zilbervarg, A.I. Yemets, O.V. Mitrofanova, and Y.B. Blume. 2003. The effect of dinitroaniline and phosphorothioamidate herbicides on polyploidization in vitro of Nepeta plants. Cell Biol. Intl. 27:229-231.

New Zealand Plant Conservation Network. n.d. Hedychium gardnerianum. 9 July 2019. <http://www.nzpcn.org.nz/ flora_details.aspx? ID $=4063>$.

Oates, K.M., T.G. Ranney, and D.H. Touchell. 2014. Campsis $\times$ tagliabuana 'Chastity': A highly infertile triploid trumpet vine. HortScience 49:343-345.

Pemberton, R.W. and H. Liu. 2009. Marketing time predicts naturalization of horticultural plants. Ecology 90:69-80.

Pheloung, P.C., P.A. Williams, and S.R. Halloy. 1999. A weed risk assessment model for use as a biosecurity tool evaluating plant introductions. J. Environ. Mgt. 57:239-251.

Pimentel, D., R. Zuniga, and D. Morrison. 2005. Update on the environmental and economic costs associated with alien-invasive species in the United States. Ecol. Econ. 52:273-288.

Pyšek, P. and D.M. Richardson. 2010. Invasive species, environmental change and management, and health. Annu. Rev. Environ. Resources. 35:25-55.

Queensland Government. 2016. Weeds of Australia. Biosecurity Queensland edition. 9 July 2019. <https://keyserver. lucidcentral.org/weeds/data/media/ Html/erythrina_x_sykesii.htm>.

Ranney, T.G. 2000. Polyploid: From evolution to landscape plant improvement.
1 Feb. 2017. <http://www.ces.ncsu.edu/ fletcher/programs/nursery/metria/ metrial l/ranney/polyploid.htm>.

Reichard, S.H. and P. White. 2001. Horticulture as a pathway of invasive plant introductions in the United States. Bioscience 51:103-113.

Russell, G. 2004. Stomatal guard cell measurements using leaf imprints. J. Cymbidium Soc. Amer. 4(3):137-139.

St. Marseille, P. and W. Grant. 1997. Segregation by morphological analyses of trisomy types in Lotus tenuis (Fabaceae). Can. J. Bot. 75:1209-1214.

Staples, G., R.H. Cowie, and Hawaii Biological Survey. 2001. Hawaii's invasive species: A guide to invasive plants and animals in the Hawaiian Islands. Mutual Publishing, Honolulu, HI.

Strachan, S.D. and D.A. Hess. 1983. The biochemical mechanism of action of the dinitroaniline herbicide oryzalin. Pestic. Biochem. Physiol. 20:141-150.

Tambong, J., V. Sapra, and S. Garton. 1998. In vitro induction of tetraploids in colchicine treated cocoyam plantlets. Euphytica 104:191-197.

Thao, N., K. Ureshino, I. Miyajima, Y. Ozaki, and H. Okubo. 2003. Induction of tetraploids in ornamental Alocasia through colchicine and oryzalin treatments. Plant Cell Tissue Organ Cult. 72:19-25.

U.S. Department of Agriculture. n.d. Invasive plants. I June 2018. <https://www.fs. fed.us/wildflowers/invasives/index.shtml>.

Vainola, A. 2000. Polyploidization and early screening of Rhododendron hybrids. Euphytica 112:239-244.

van Tuyl, J.M., B. Meijer, and M.P. van Dien. 1990. The use of oryzalin as an alternative for colchicine in in-vitro chromosome doubling of Lilium. Lily Yrbk. North Amer. Lily Soc. 43:19-22.

Vilà, M., J.L. Espinar, M. Hejda, P.E. Hulme, V. Jarošík, J.L. Maron, J. Pergl, U. Schaffner, Y. Sun, and P. Pyšek. 2011. Ecological impacts of invasive alien plants: A meta-analysis of their effects on species, communities and ecosystems. Ecol. Lett. 14:702-708.

Vining, K.J., R.N. Contreras, M. Ranik, and S.H. Strauss. 2012. Genetic methods for mitigating invasiveness of woody ornamental plants: Research needs and opportunities. HortScience 47:1210-1216.

Wickert, K., E. O’Neal, D. Davis, and M. Kasson. 2017. Seed production, viability, and reproductive limits of the invasive Ailanthus altissima (tree-of-heaven) within invaded environments. Forests 8:226. 